\title{
THE EFFECT OF DIVIDED GOVERNMENT AND THE INCUMBENT LEADER ON THE ECONOMIC GROWTH IN INDONESIA
}

\author{
Nairobi1), Ambya2) \\ Faculty of Economics and Bussines, University of Lampung,Indonesia \\ 1)nairobi.saibi@gmail.com, ${ }^{2)} \underline{\text { ambya.mahmud@gmail.com }}$
}

\begin{abstract}
The purpose of this research is to know the effect of the divided government and the incumbent government on the economic growth in regions and cities in Indonesia. This research uses 157 regions and cities which had run the regional election in June till August in 2005 as the sample. This is due to the perception of how the regional election had just begun in 2005 while the next and the upcoming election were held in 2010. By far, the data is taken until the end of 2010 to picture the progress of the governmental performance during the period of the leadership of the incumbent leader. As a result, it is found that the incumbent leader has a negative effect on economic growth. This can be seen on the differences between the area with the new leader and the incumbent leader. There are several causes that lead to these results. First, it shows that the voters have not yet evaluated the performance during the leadership period. Second, because the incumbent leader is in the last period of their leadership, they tend to maximize their personal and their group interest, as well as their party, which is resulted to the ignorance of economic growth. Another key finding is that divided government has no effect on economic growth. In Indonesia, the regional leader anticipates the issue of the divided government by doing accommodative politics for the representative member of the regional house (DPRD). Instead of only becoming the checker and balancing power, this action is taken to support all the actions of the regional leader. Thus, it is confirmed that there is no difference between the divided or unified government.
\end{abstract}

Keywords: divided government, incumbent government, economic growth, incumbent leader, regional leader

Copyright (C) 2020, International Journal of Economics, Business and Entrepreneurship | IJEBE | FEB-UNILA

\section{INTRODUCTION}

In order to enhance the democracy inside the government in Indonesia, one reformation agenda that has been implemented since 2001 is about the autonomy and regional decentralization. Regional decentralization is about handover power, authority, resources, finance, and responsibilities from the central government to the local region. With the purpose to accelerate the development and welfare enhancement, the divided work or responsibilities is all based on the authority of the centrally government. In other words, it aims to open bigger opportunities for the regional government to develop and make use of the entire region's potential for social welfare. The governmental implementation plan on the autonomy era guarantees the running of the democratic principles; rising the community participation in public decision making, transparency, 
accountability, and public responsibility. Those principles prioritize the sharing of power between the nation's institution, notably on the executives and legislative institution.

Law No. 31 of 2004 states that the regional government is being managed by the elected regional leader and its vice through direct election, with a single or group of political parties. The changes from Law No. 32 of 2002 to Law No. 12 of 2008, Section 58, subsection $1 \mathrm{~b}$ states that the candidate of the regional leader can also be proposed as an individual candidate that is supported by some amount of people. After the regional election in 2005, new phenomenon rises, called a divided government. Divided government happens when the regional head does not come from a single party with the majority of members on the regional House of Representatives. On the other hand, the unified government happens when the regional head comes from a single party and gains the majority of the members of the house representative. Based on the survey from Lingkar Survei Indonesia (LSI) in 2007, up to December 2006, there were 290 regions using divided government after they held the regional election (LSI, November 2007).

The phenomenon of divided government is also supported by the implementation of Law No. 12 of 2008, stating that the regional leader and the members of the house of representative are equals partner in doing their responsibilities as the operation of the region. As a matter of fact, in practice, it is found that one of the sides is more dominant, resulted in conflict between these two institutions and affected the effectiveness of public service. Divided government in a democratic nation has also impacted the effectiveness of government performance and the direction of the public policy. The idea has also been discussed by Epstein and O'Halloran 1996; Coleman, 1999; Wu, 2003; Streb and Torrens, 2009; Schelker, 2011.

Table 1 shows how the relationship between the legislative and executives, as well as how many of the members of the house representative supporting the government. If there are less than $51 \%$ of the total amounts of house representatives that are supporting the regional head, then it is called as a divided government. On the contrary, if there are more than $51 \%$ of the total amounts of house representatives that are supporting the head of a region, then it is called as a unified government. 
Table 1. The Form of the Regions and Cities from the Samples

\begin{tabular}{|c|c|c|c|c|c|c|c|c|}
\hline \multirow{3}{*}{ ISLAND } & \multicolumn{2}{|c|}{$\begin{array}{l}\text { UNIFIED } \\
\text { REGIONS }\end{array}$} & \multicolumn{2}{|c|}{$\begin{array}{l}\text { DIVIDED } \\
\text { REGIONS }\end{array}$} & \multicolumn{2}{|c|}{ UNIFIED CITY } & \multicolumn{2}{|c|}{ DIVIDED CITY } \\
\hline & & & noun & & amoun & & & \\
\hline & amount & $\%$ & $\mathrm{t}$ & $\%$ & $\mathrm{t}$ & $\%$ & amount & $\%$ \\
\hline Sumatera & 6 & 5.13 & 24 & 20.51 & 0 & 0 & 14 & 35.00 \\
\hline Java and Bali & 9 & 7.69 & 48 & 41.03 & 0 & 0 & 14 & 35.00 \\
\hline Nusa Tenggara & 0 & 0.00 & 4 & 3.42 & 0 & 0 & 2 & 5.00 \\
\hline Borneo & 2 & 1.71 & 12 & 10.26 & 1 & 2,50 & 4 & 10.00 \\
\hline $\begin{array}{l}\text { Sulawesi } \\
\text { and Maluku }\end{array}$ & 8 & 6,84 & 4 & 3.42 & 3 & 7.50 & 2 & 5.00 \\
\hline TOTAL & 25 & 21.37 & 92 & 78.63 & 4 & 10.00 & 36 & 90.00 \\
\hline
\end{tabular}

Source: KPU and Dirjen OTDA Kementerian Dalam Negeri (data has been databases from the result of the legislative election in 2004 and the regional election).

From Table 1, it can be concluded that there are 25 government areas (21\%) are unified government, and 92 areas (79\%) are divided government. Contrary to the cities, only four cities (1\%) from a total of 40 cities that are unified government and 36 cities $(90 \%)$ are actually divided government. Generally speaking, 40 sample areas (18\%) are included as a unified government, and the rest of 128 areas (82\%) are divided government.

A further point to note is that Java has the most regions with divided government, followed by Sumatera, Borneo, Bali, and Nusa Tenggara respectively. In contrast, Sulawesi and Maluku have the most areas with a unified government. For cities, Sumatera, Java, Bali, and Nusa Tenggara are marked as divided government. Borneo, Sulawesi, and Maluku are the only cities with a unified government.

Another phenomenon that happens after autonomy and regional decentralization is a large number of incumbent regional leaders that once again proposed them to be a regional leader in the next election. From the total number of 290 areas doing the regional election, 230 incumbents $(78.77 \%)$ want to run the government for the next period. From those numbers, 143 (62.17\%) are winning the election (LSI, June 2007). the phenomenon of incumbent delegates to winning reelection is common. In America, the chances for the incumbent to re-elect again are quite high.

As a matter of fact, there are multiple reasons and advantages that strongly favor the incumbent. First, they prospectively more popular since they can do permanent campaign when they are still running on the government (LSI, 2007). In terms of the cost of a political campaign, the incumbent can use up the government budget to be re-elected. For instance, with the use of government funds for projects solely to bring money to the parties or what we called as pork-barrel politics.

Table 2 reveals the comparison between incumbent and non-incumbent based the list on island areas, as well as the cities. There are 72 areas (62\%) have incumbent leaders, and 45 areas (38\%) have new regional leaders. In total, it can be seen that there are 97 areas $(62 \%)$ have chosen incumbent leaders and the rest of 60 areas (38\%) is a newcomer. 
Table 2. The Chosen Regional Leaders' Status in Area of Indonesia

\begin{tabular}{|c|c|c|c|c|c|c|c|c|}
\hline \multirow{2}{*}{ ISLAND AREA } & \multicolumn{2}{|c|}{$\begin{array}{l}\text { INCUMBENT } \\
\text { REGIONS }\end{array}$} & \multicolumn{2}{|c|}{$\begin{array}{l}\text { NEWCOMERREG } \\
\text { IONS }\end{array}$} & \multicolumn{2}{|c|}{$\begin{array}{l}\text { INCUMBENT } \\
\text { CITIES }\end{array}$} & \multicolumn{2}{|c|}{$\begin{array}{l}\text { NEWCOMER } \\
\text { CITIES }\end{array}$} \\
\hline & amount & $\%$ & amount & $\%$ & amount & $\%$ & amount & $\%$ \\
\hline Sumatera & 17 & 14,53 & 13 & 11,11 & 10 & 25,00 & 4 & 10,00 \\
\hline Java and Bali & 36 & 30,77 & 20 & 17,09 & 8 & 20,00 & 6 & 15,00 \\
\hline Nusa Tenggara & 4 & 3,42 & 1 & 0,85 & 2 & 5,00 & 0 & 0,00 \\
\hline Borneo & 11 & 9,40 & 3 & 2,56 & 4 & 10.00 & 1 & 2,50 \\
\hline $\begin{array}{l}\text { Sulawesi and } \\
\text { Maluku }\end{array}$ & 4 & 3,42 & 8 & 6,84 & 1 & 2,50 & 4 & 10,00 \\
\hline TOTAL & 72 & 61,54 & 45 & 38,46 & 25 & 62,50 & 15 & 37,50 \\
\hline
\end{tabular}

Source: KPU and Dirjen OTDA Kementerian Dalam Negeri (data has been processed from the result of the Legislative election in 2004 and the regional election)

Table 2 above shows that Java has the most numbers of incumbent leaders, followed by Sumatera, Java, Borneo, Bali, and Nusa Tenggara. On the other hand, Borneo and Maluku have the least numbers of incumbent leadership. For the cities, Sumatera has the most numbers of incumbent leaderships, followed by Java and Borneo. On another note, Nusa Tenggara, Sulawesi, and Maluku had the least number of incumbent leaderships.

The purpose of a regional election was to accelerate the democracy consolidation and the good government since it involves the citizen directly into the policymaking. Besides, some argumentation and assumption have supported on how the importance the regional election is. First, it is more possible to elect accountable and qualified leader within the regional election. Second, the regional election is needed to create political stability and the effectiveness of the government at the local base. Third, the regional election improves the prosperity of the community through economic development. Hence, a regional election can build better governance, either with the divided or unified government; and, both are equipped with the incumbent or new leader. The diversity of the government and leadership are definitely brought different advantages to the community.

\section{LITERATURE REVIEW}

Basleyet et al. (2007) state that individual usually makes the decision of their vote based on the economic dimension that is related to the economic performance during the leadership period. However, in some cases, ideology dimension has also taken the part in non-economic factors, for instance, religion, race, nationality, and many more. If the ideology becomes more relevant, then it will lessen the voters' sensitivity on the economic problem. Hence, it becomes beneficial for one party in the proportional representation elections (political rants). The less accountable the candidates are, the less quality of the politician may be offered by the party. They are might against growth and only looking for the political position to overrule the politics. Ultimately, this will affect the redistribution of the economy, in opposition to the efficiency and economic growth.

Combining the political and economic model, research about the probability of incumbent leader is being re-elected and how it affects the capital investment and the spending composition of a region, are explained by Fiva and Narvlik (2012). The research is 
done in Norway by using a data panel for 28 years. It is found that there is a high possibility for incumbent leader will be re-elected again to stimulate the investment, especially on the favourite programs that have been created by the incumbent leader. The data reveals how capital and government spending are included as complementary input for government production activity.

Costa-Font, Rodriguez-Oreggia, and Luna-Pla (2003) explain how political competition in the local election affects the regional public investment allocation in Mexico. By using the simultaneous model, it is found that the regional public investment allocation by the government is being pushed for the political opportunity and the local pork-barrel politics. Public investment is used as a way to bring support favouring the incumbent political party.

Mayhew (1991) analyses on the relationship of American presidential with their legislative roots between 1946 until 1990, he concludes that there is no such a big different result between the divided government and the unified government. It showed that the split government will not cause a dead-end legislative or any differences in the policy result.

Ideally, the present leader's parties should have more power on the executives and legislative; while, the opposition will play the role of supervising. However, if the divided government is filled with many different parties inside it-having different blocks of power for the executives and the legislative-then, it will eventually weaken the control of the ruling party, since both parties may conflict to each other. In other words, many different parties are a big issue that can ruin the purpose of government efficiency (Cutler, 1988; Leonard, 1991). Another point from Sundquist (1988) mentions, that a democratic regime is more focused on the working mechanism of the parties in government. A political party is the government essential instrument to bring unity, and for that reason, it can help the government to work effectively as a whole. It also creates a link between the executives and legislative for their typical interest.

Studies by Wu and Huang (2003) unveil the effect of the divided government to the performance of the major or the law enforcement at the district/city level. It uses the public evaluation survey for government performance in 2002. Their studies evaluate the citizens' perception onto the divided government and the result indicates that the public has a higher level of satisfaction with the unified government than the divided government.

Generally, the legislative or the executives need to be responsive to the needs of the community. According to Streb and Torrens (2009), an incumbent leader who has power deals with asymmetric information. It leads to the temptation to manipulate the fiscal policy in order to add more voting for them. By then, within the divided government, the fiscal policy would be more trustable if the legislative has more power to limit the power of the executive.

The ability of the voters to vote is influenced by the circumstances of the surrounding institution. Schelker (2011) states that there is a bigger tendency for about 10 $-15 \%$ when the voters deal with the leader whose period have almost over (lame duck). In order to maintain the leader accountability, then the voters would choose the opposition party at the legislative to control the executive. 


\section{METHODOLOGY}

\section{The Research Plan}

This research aims to know the effect of the political variable on the economic performance during the 5 years of the periodical leadership. The direct election for the regional leader has been implemented since June 2005 and the period of leadership will be over in June 2010. The dependent and independent variable which is used can be seen in Table 2. Each of the dependent variables is calculated in regression with the independent variable.

Table 2. The Dependent and Independent Variable

\begin{tabular}{lll}
\hline \multirow{2}{*}{ Dependent Variable } & \multicolumn{2}{c}{ Independent Variable } \\
\cline { 2 - 3 } GDP in 5 years (PDRBKAP) & 1) Divided or unified & 1) Regional investment \\
& government (DIVIDED) & (INVEST) \\
& 2) Incumbent or non & 2) Number of citizenship \\
& incumbent (INCUMBENT) & (POP GROWTH) \\
& & 3) Initial GDP (PDRB $\left.\mathrm{t}_{\mathrm{t}-1}\right)$ \\
\hline
\end{tabular}

The data is taken from several researches in 5 years (2005-2010). Therefore, only the average data during the period of leadership or the result of cross-section data from samples are being analyzed.

\section{Population and Samples}

The research population covers all the cities and districts from 505 regions in Indonesia. The research uses 157 of cities and districts which had run the election in JuneAugust 2005. The decision for the sample is based on the consideration that the direct election was just started in 2005 and the next direct election will be in 2010 . Thus, the data that is collected until the end of 2010 illustrates the development of the leaders' performances during their period.

\section{Type and Data Resource}

This research uses secondary data, describing the average variable improvement on the 157 regions as the sample. The resource of these data is from Centre Statistical Bureau, both from the central and region, the Election Commission; central and region, and other institutions.

\section{Model and Data Analysis Method}

This research uses development model from Ashworth et al. (2006), Besley (2008), Padovano and Riccuti (2009), Pereira and Teles (2009):

ECONOMIC GROWTH = $\mathrm{f}\left(\right.$ POLITICAL COMPETITION $_{\mathrm{i}}$, CONTROL VARIABLE $\left._{\mathrm{i}}\right)$ 
The variable of ECONOMIC GROWTH is to measure the economic development upheld by the regional government. VARIABLE CONTROL $\mathrm{L}_{\mathrm{i}}$ is the variable out of the political competition which has the influence for the economics performances, consisting of three variables and VARIABLE COMPETITION $\mathrm{N}_{\mathrm{i}}$ is the variable describing how the political competition is happening and consists of two variables.

Besides that, this research uses the Levine and Renelt analytical model (1992):

Notes:

$$
\mathrm{Y}=\beta_{i} \mathrm{I}+\beta_{m} \mathrm{M}+\beta_{z} \mathrm{Z}+\mu
$$

Y

$=$ Economic Growth

$=$ Variable of Growth Function

M

= Variable of the Researcher's Interest

$\mathrm{Z}$

= Supporting Variable of the Researcher's Interest

$\mu$

$\beta_{i,} \beta_{m,}$ dan $\beta_{z}$

= Error term

$=$ Regression coefficient of each variable

Then that model is transformed into double regression equation OLS as follows:

ECONOMIC GROWTH $\mathrm{H}_{\mathrm{i}}=\mathrm{b}_{0}+\mathrm{b}_{1}$ INVEST $_{\mathrm{i}}+\mathrm{b}_{2}$ POPGROWTH $_{\mathrm{i}}+\mathrm{b}_{3}$ INITIAL GROWTH $_{\mathrm{i}}+$ $\mathrm{b}_{4}$ DIVIDED $_{\mathrm{i}}+\mathrm{b}_{5}$ INCUMBENT $_{\mathrm{i}}+\mathrm{b}_{6}$ PDRB $_{\mathrm{t}-1}+\mathrm{u}_{\mathrm{i}}$

\section{Operational Definition and Variable Measurement}

This research uses the definition and variable measurement in Table 3 below:

Table 3. Type and Operational Definition of Variable

Type of variables $\quad$ Operational definition and its measurement

1) Average Growth Is the average of GDP in 5 years development based on the constant PDRB percapita in 5 price year 2000, in a percentage. The data resource is from the years (ECONOMIC Statistical Bureu of Indonesia. GROWTH)

2) Divided or unified Government

Is the dummy variable, value as 1 if it is the divided government and (DIVIDED)

3) Incumbent or non incumbent valued as 0 if it is the unified government.

(INCUMBENT)

4) Average of Is the dummy variable, valued as 1 if it isincumbent and valued as 0 if it was non incumbent.

Regional investment (INVEST)

5) Growth of Populations (POP GROWTH)

6) Initial $P D R B_{t-1}$ (INITIAL GROWTH)

Is the realization of the 5 years average of investment. The data resources from GDP investment. The data resource is from Statistical Bureau of Indonesia.

Is the 5 years growth of population.

Is the initial growth. The data resource is from Statistical Beureu of Indonesia. 


\section{DISCUSSION}

Table 4 shows the estimation result based on the structural equation model that has been prepared.

Table 4 The Result of Dependent Variable: ECONOMIC GROWTH

\begin{tabular}{lcc}
\hline \hline \multirow{2}{*}{ Dependent Variable } & \multicolumn{2}{c}{ Equation Model } \\
\cline { 2 - 3 } Constanta & $-0,34^{* * *}$ & II \\
DIVIDED & $(-4,27)$ & $-0,21^{* * *}$ \\
& $-0,00$ & $(-5,34)$ \\
INCUMBENT & $(-0,44)$ & $-0,00$ \\
& $-0,02^{* *}$ & $(-0,62)$ \\
INITIAL GROWTH & $(-2,02)$ & $-0,03^{* *}$ \\
& $0,01^{* * *}$ & $(-2,94)$ \\
INVEST & $(4,43)$ & $0,06^{* * *}$ \\
& $0,06^{* * *}$ & $(4,80)$ \\
POP GROWTH & $(4,77)$ & $0,04^{* *}$ \\
& 0,00 & $(3,03)$ \\
Dummy Java & $(0,32)$ & 0,00 \\
& & $(0,40)$ \\
Dummy Cities & & $-0,00$ \\
& & $(-0,18)$ \\
\hline \hline Number of observation & 157 & 0,00 \\
Adjusted $R^{2}$ & 0,35 & $(0,24)$ \\
F-statistic & $5,59^{* * *}$ & 157 \\
\hline Source: Estimation Result $(\ldots)$ t-statistic $(*)$ significant $\alpha=10 \% ;$ & $\left.5,88^{* * *}\right)$ significant $\alpha=5 \% ;(* * *)$ \\
significant $\alpha=1 \% ;$ & &
\end{tabular}

It is proven that the incumbent variable has a negative effect on economic growth. There is a difference between regions being directed by the incumbent leader compared to the region lead by the new leader. The region that is being run by incumbent leader has 0,03\% lower economic growth compared to the region which is led by the new leader. According to Bardhan and Yang (2004), related to the political competition as the accountability of an incumbent leader "political turnover", a tight political competition stimulates the economic growth. It is due to how the incumbent leader tries to maintain their power by directing the policy to economic growth. On the contrary, if there is too tight political competition-when there is powerful threat to over-rule the incumbent leaderthe incumbent leader by then will do a myopic action by taking advantages as much as possible for their and their group interest until the end of their leadership period. Fiva and Natvlik (2012) do research in Norway and find how high the possibility of an incumbent leader to be chosen again will stimulate investment. In spite of that, this kind of investment will only for the incumbent leader's interest. The national asset and finance are used as their tools to support their campaign. 
An incumbent in the Indonesian election will be the final period to join the election or politically called as a lame duck. Simply put, they are not able to sit as a leader for the third time. This condition shows how a leader will maximize their personal interest and their party by doing a political opportunist and a local politic called "pork-barrel". As has been said, it is done to maintain the benefit of the power for their party Costa-Font, Rodriguez-Oreggia, and Luna-Pla (2003) finds that this kind of behaviour had happened in Mexico in 1990-1995. Snowdon (2004) states that voters can evaluate their vote to choose the same person again or choose a substitute to lead a region based on the performance result of its leadership. For a success leader who has developed its region during its period of leadership, people will reward the leader by choosing that particular person one more time. On the other side, if the leader has failed to develop its region, then people will give consequence by not choosing the same person again.

Nevertheless, does the political evaluation happen in Indonesia? Based on a survey done by LSI (2007), the result shows that the voters have not evaluated the election maximally. Some incumbent leader has been re-elected for the second time, even though they have failed to gain the economics, politics, security and the law enforcement conditions. The voters tend to choose the incumbent leader because of the popularity factors, not on their achievement.

This paper reveals that there is no significant effect between divided or unified government to economic growth. The same research done by Mayhew (1991) states that there is not a big difference between the divided or the unified government. The divided or unified government will not cause a dead end between the executives in planning and implementing the policies. In contrast, some researchers state that the divided government tends to be the factor of the inefficiency and dead end of the executives and the legislative. The divided position between the legislative and executives would lead to a policy conflict. $\mathrm{Wu}$ and Huang (2003) do research at the city or region level to know the citizens' perception of the government. The public believes to have higher satisfaction with the unified government compared to the divided government. Streb and Torrens (2009) stated that the divided government has a more efficient and trustable policy if the legislature has the power to limit the executive policy, by implementing the rule or by having check and balance for both sides.

In Indonesia, to overcome the problem of divided government, the leader will do the anticipation by doing an accommodative politics. There are three types of accommodative politics which are used by the leader; first, by putting other people from different parties inside the bureaucracy to prove that this policy still, in fact, a part of legislative responsibility. Second, by giving incentive to the member of the regional house representative. Providing incentive can be done by adding the salary, additional monetary reward, and other facilities. The fund of this incentive come from the regional budget. Thirdly, by bribing the member of the regional house representative and or doing a massive corruption, so that the divided government will not become a check and balance. This will push the regional leader to find ways incorporating those issues that bring loss to the community.

The Initial level shows a positive sign. This reveals how the regions' growth in Indonesia leads to divergence: the income gap rises, where the rich region grows faster compared to the poor region. Based on the research about the convergence of growth and income gap, the chosen leader has not tried to decrease the income gap for their period of leadership. Having the same idea with the research from Heriqbaldi (2009), it is found that 
in some provinces; East Java, West Java, and Central Java, the economic growth in 2004 2007 led to divergence growth. The research from Masfufah (2013) shows the same result by using the GDP approach and the spending approach, analyzing the factors of disparities between regions in Indonesia in 2006 - 2010. The result reveals that income convergence does not happen in regions/cities in Indonesia.

The Economic growth is divergence happens because of the difference in the endowment factors from each region. Some regions and cities in Java Island have big endowment factor, particularly on human resource and technology. Certainly, the centralization of goods and service production are frequently taking place in those areas. Meanwhile, in some regions in Java, Borneo, and Sulawesi, the endowment factors are the natural resources, like oil and gas, coal, and other minerals. Regions with opportunities, such as human resource, technology, and natural resources will grow faster compared to the areas with no advantages.

However, at the national level, some research shows that 86 countries in 1960 1985 have convergence in the growth of real PDB, Levine, and Renalt (2009). Vijayaraghavan and Ward (2001) use 43 crosses countries in 1975 - 1990 and they find the same issue. Research by Fatas and Mihov (2013) use 87 countries in 1970 - 2007; have also found the convergence in the economic growth.

The investment is positively affecting the economic growth in each region. Tajerin (2007) finds the same result. The rate of physical investment growth has positively influenced the speed of growth of real GDP in 5 years in east Indonesian. Levine and Renalt (1992) find the same result showing that economic growth has positively affected the economic growth across the nation. The growth of population does not influence of economic growth. This has been predicted by Levine and Renalt (1992), they find that from a total of 43 countries discussed, the population growth seems to have a fragile relationship with economic growth. There was no significant difference between the economic growth of between Java and Bali or outside of Java and Bali. Based on the economic growth, it is visible that the average Product Domectic Regional Bruto percapita between regions are no avail either. This is due to the same growth pattern on Product Domestic Regional Bruto percapita between regions.

\section{CONCLUSION AND SUGGESTION}

The result reveals that the incumbent leader has a negative influence on economic growth. There are differences found in the regions led by the incumbent leader and nonincumbent leader. In point of fact, the economic growth of the region led by the incumbent leader has shown lower level compared to the region led by a new leader. The reasons for this issue are; firstly, the voters do not evaluate the performance of the incumbent leader and tend to choose the previous leader for the sake of popularity; next, the leadership period of the incumbent leader is the last chance for another period of leadership. This will stimulate the leader to maximize their interest, their group, and their party. Therefore, they become ignorant to the economic growth.

There is no evidence found to associate divided government with economic growth. In Indonesia, the regional head uses accommodative politics to anticipate the issue of the divided government. In order to gain support, accommodative politics try to accommodate the regional house representatives. Consequently, the member of the house representative 
is losing their value and power to check and balance. Thus, the effect between the divided government or the unified government is none to see.

The controlled variable or the initial level is shows a positive sign. The economic growth leads to a divergence growth: the rich regions grow faster than the poor region, increasing the income gap. The other controlled variable, which is, the real investment ratio, have a positive influence on the growth of the real GDP in 5 years. The higher the investment ratio, the higher will be the economic growth in each region. The population growth number has no influence on economic growth.

On the regional side, there are no differences between Java and Bali Island compared to the other areas. The result finds no difference in economic growth found between either the cities or the regions. It happens for the reason of political competition and the typical pattern of economic growth among the areas.

These results find that the incumbent leader has negative influences against economic growth. The economic growth which is led by the incumbent leader has a lower level compared to the regions lead by a new leader. Taking this into account, stronger policies are needed to control the supervision. In addition, firmer rules are also required to avoid the misuse of budget and spending plan for the election campaign of the regional head.

There are pieces of evidence show that the economic growth of the region lead by the incumbent leader is lower than the regions lead by a new leader. Does this happen because the leader focuses more on their own interest, their group, their party or their families? Further research is needed to reveal the issue.

This research only focuses on seeing the political competition in the year of 2004, the election in 2005, 2006 and 2007. This condition caused by the transition of democracy system happens in Indonesia. Further research configuring the legislative election in 2009 and 2014 is needed to explain the political condition comprehensively. 


\section{ACKNOWLEDGEMENT}

In writing this paper the authors also thank the parties who have helped in the preparation of this paper either directly or indirectly for the sake of perfection substantially. The institution of Universitas Bangka Belitung (UBB) and the faculty of economics and business Universitas Lampung (UNILA) is also one of the few parties that have been very helpful for the smooth writing of this paper. 


\section{REFERENCES}

Ashworth, J., Geys, B., Heyndels, B., \& Wille, F. 2006. Political competition and local government performance: evidence from Flemish municipalities. Mimeo.

Bardhan, Pranab., \& Yang, Tsung-Tao. 2004. Political Competition in Economic Perspective. Economics Department Publication. University of California, Berkeley. http://iber.berkeley.edu/Wps/econwp.html. Accessed

Besley, Timothy J. \& Preston, Ian . 2007. "Electoral Bias and Policy Choice: Theory and Evidence", Quarterly Journal of Economics, 122, pp. 1473-1510.

Coleman, John J. 1999. Unified Government, Divided Government, and Party Responsiveness. American Political Science Review, 93(4), 821-835.

Costa-Font, Joan., Rodriguez-Oreggia, Eduardo., \& Luna-Pla, Dario. 2003. Political Competition and Pork Barrel Politics in the Allocation of Public Investment in Mexico. Public Choice 116, 185-204.

Cutler, Lloyd N. 1988. Some Reflection about Divided Government. Presidential Studies Quartly, 485-492.

Epstein, David \& O'Halloran Sharyn. 1996. Divided Government and the design of Administrative Procedures: A Formal Model and Emperical Test". The Journal of Politics, 58(2), 373-397.

Fatás, Antonio., \& Mihov, Ilian. 2013. Policy Volatility, Institutions, and Economic Growth. The Review of Economics and Statistics, MIT Press, 95(2).

Fiva, Jon H., \& Natvik, Gisle James. 2012. Do Re-election Probabilities Influence Public Investment? Public Choice. https://doi.org/10.1007/s11127-012-9946-8.

Heriqbaldi, Bukit. 2009. Konvergensi Tingkat Pedapatan, Studi Kasus 3 Propinsi di Pulau Jawa. Journal of Indonesian Applied Economics, 3(1), 77-88.

Leonard, John. 1991. Divided Government and Dysfunctional Politics. Political Science and Politics, 24(4), 651-653.

Levine, Ross., \& Renelt, David. 1992. A Sensitivity Analysis of Cross-Country Growth Regressions. The American Economic Review, 82(4). 942-963.

Lingkar Survei Indonesia. 2007. Incumbent dan Pilkada. Kajian Bulanan LSI. Edisi 02, Juni.

Lingkar Survei Indonesia. 2007. Hukuman dan Ganjaran dari Pemilih. Kajian Bulanan LSI, Edisi 02, Juni.

Lingkaran Survei Indonesia. 2007. Pilkada dan Pemerintahan Terbelah. Kajian Bulanan LSI. Edisi 07, November. 
Masfufah. 2013. Konvergensi dan Faktor-Faktor yang Mempengaruhi Disparitas Wilayah Kabupaten /Kota Di Indonesia. Sosio humaniora, 15(2), 194 - 202.

Mayhew, David. 1991. Divided We Govern. New Haven. Yale: University Press.

Padovano, F., \& Ricciuti, R. 2009. Political Competition and Economic Performance: Evidence From the Italian Regions. Public Choice, 138(3), 263-277.

Pereira, Carlos., \& Teles, Vladimir Kühl. 2009. Political Institutions as Substitute for Democracy: A Political Economy Analysis of Economic Growth. Escola de Economia de São Paulo da Fundação Getulio Vargas FGV-EESP, Mimeo.

Schelker, Mark. 2011. Lame ducks and divided government: How voters control the unaccountable. Discussion Paper no. 2011-30 July 2011. School of Economics and Political Science, Department of Economics University of St. Gallen.

Snowdon, Brian, 2004. The Influence of Political Distortions on Economic Performance The Contributions of Alberto Alisena. World Economics, 5(4), September.

Streb, Jorge M., \& Torrens, Gustavo. 2009. Making Rules Credible: Divided Government and Political Budget Cycles. Mimeo.

Sundquist, James L. 1988. Needed: A Political Theory for The New Era of Coalition Government in The United States. Political Science Quarterly 103, 614-624.

Tajerin. 2007. Peranan Teknologi dalam Konvergensi Pertumbuhan Ekonomi Antar Daerah Pesisir di Kawasan Timur Indonesia. Jurnal Ekonomi Pembangunan, 12(3), 179-194.

Vijayaraghavan, Maya \& Ward, William A. 2001. Institutions and Economic Growth: Empirical Evidence for a Cross-National Analysis. Working Paper 001312 Center for International Trade.

Wu, Chung-li \& Chi Huang. 2007. "Divided Government in Taiwan's Local Politics: Public Evaluations of City/County Government Performance", Party Politics vol13: 741-760.

$\mathrm{Wu}$, Chung-li. 2003. Local factions and the Kuomintang in Taiwan's electoral politics. International Relations of the Asia-Pacific, 3(1), 89-111. 